\title{
IAMJ
}

INTERNATIONAL

AYURVEDIC

MEDICAL JOURNAL

\section{SŪSRŪTA SYSTEM OF INTENSIVECARE -A PROSPECTIVE OVERVIEW}

\author{
Rinky Thakur ${ }^{1}$, Gopal C Nanda ${ }^{2}$, Binodini Tripathi ${ }^{3}$, Shashidhar H Doddamani ${ }^{4}$ \\ ${ }^{1,4}$ Research Officer (Ay.), Regional Ayurveda Research Institute for Metabolic Disorder, (Central Council for \\ Research in Ayurvedic Sciences), Bengaluru \\ ${ }^{2}$ Director Ayurveda Geriatric Care and Research Centre, Bhubaneswar, Odisha, India \\ ${ }^{3}$ Principal IGM Ayurveda medical College and hospital, Bhubaneswar, Odisha, India
}

Corresponding Author: rinkygharsangi@gmail.com

https://doi.org/10.46607/iamj2408082020

(Published online: August 2020)

Open Access

(C) International Ayurvedic Medical Journal, India 2020

Article Received:18/07/2020 - Peer Reviewed:04/08/2020 - Accepted for Publication:06/08/2020

\section{Check for updates}

\begin{abstract}
In Vŗhatryee, Süsrūta has the doctrine of surgical management along with related descriptions of anatomy, physiology. Though Charaka and Vägbhata have similar description but are not up to the content like Süsrüta. Süsrüta was the first who described surgical operations and had broad view on sterilization pre and post-operative management along with intensive care which are unique and has prime importance. In modern system of medicine intensive care plays a vital role for patient's life and sustenance. It was interesting to evaluate that Süsrüta system of intensive care has been described considering all aspects where he has given importance to the major specialties required. In the line of shlokas all the meanings are buried and are yet to be understood in the line of description. It is also very important to know that the present system of surgery though so advanced but also existed before 1000 B.C and which is clearly evident from the description found. Süsrūta had felt the necessity of multispecialty physician cum surgeon's advice during critical care as per the prevailing system. During Süsrüta time different names (probably nominated specialists of different wings) were given due importance to the critical management of the patients are usually seen nowadays in modern system of medicine. In the present paper efforts have been taken to decipher the every term used by Süsrüta in parlance to modern system concerned to ancient system of critical care.
\end{abstract}




\section{INTRODUCTION}

The great scientist Aldus Manutius has told "Never to allow scholars to want for good books of literature and sciences." He was the house where scholars and physicians crowded for help, co-operation and guidance. His name is remembered by future generations by rescuing the priceless works on arts and science of ancient Greeks. He can well serve as guidance and an example for advancement of our knowledge, culture and learning. It is in view that our oldest and authoritative classics of medicine-Charaka, Süsrūta need hundreds of editions together with their translation, commentaries etc. which we do not have, moreover each commentary may throw some light on many significant and potent descriptions which need more extensive and lucid interpretations to be clearly understood for coming generations.

Sūsrūta Saminhtā is a treatise of universal importance. It is one of Vedas of science of medicine in India and so various commentators from various countries have done work on it according to each one's predilection. There are translations of Süsrūta in various languages both of east and west. Yet it is not only desirable but essential to have as many translations and commentaries as possible for the enlightenment and elucidation of classical work on surgery like Sūsrūta Samhitā. Thousands of years back the names of Süsrüta and Charaka found within the text of $4^{\text {th }}$ centuary.The first Charaka and Süsrūta Samhitā were translated into Arabian and Persian language during $7^{\text {th }}$ century in the name Saraka \& Sasarada. Almansur (753-754 BC) had translated Süsrūta Samhitā where he had made Susruta more potential and important due to clear classification of all the branches of Ayurveda. Interestingly Charaka has left the part of surgical intervention by admiring the expertise as-

\section{"Atradhanvantaryānāṃkriyavidhauparādhikare- tunahvistaroktih"Charaka}

As a matter we find the description of Medicine equally with that of Charaka and with surgical section.

So far identity of Süsrüta is concerned; he is believed to be son of vishvamitra from the available texts written by him and in subsequent commentaries etc. The time of Sūsrūta dates back to 1000 B.C. Different time spells have been embarked by different western researchers like $12^{\text {th }}$ centuary by Hass, $9^{\text {th }}$ to $10^{\text {th }}$ cent.by Jones Wilson, $4^{\text {th }}$ B.C.by Maedonel. Interestingly Hobert has not accepted Süsrüta as specific other than Sacretes. From the writing "Apāyahridaya" of Arya Nāgārjuna it is believed that Sūsrüta placed in 2000 BC.

"Suvaidhyakobhesajhkushalomaitrachitteshikshakasūsrüta",

However, Hasler who has translated Sūsrüta into latin has placed him 1000BC which is being supported by Girindranathmukhopadhyaya the philosopher. Looking into the context we may accept the view of historians as approximate 3000 years from today. Similarly, the text Vrrdha Sūsrūta in comparison to Süsrūta Samhitā is also of matter relating to uttarsthāna causing deep study for non-identical description in both the text. However, it is very sensational issue and needs to be debated with research findings.

"Kwasuryaprabhavovanshakwachaalpavishayamati Titirshudushtarammohadudupenasminsagaram ',

\section{Kalidas}

\section{Material and Methods}

So far Süsrūta Samhitā is concerned it is having 120 chapters in which each sthana has its own specifications and uniqueness: Sutra sthāna-46 , Nidāna sthāna-16, Shārirasthāna-10, Chikitsāsthāna-40, Kalpasthāna-8, Uttartrantra-66, Acharya Susruta has described 300 types of surgical procedures, division of human surgery eight categories, 60 types of upkramas(therapeutic methods )for treatment of wound, antiseptic, induced anesthesia using wine and cannabis indica and also mentioned 120 types of yantras and shastras (surgical instruments). He has introduced nasasandhan (rhinoplasty), oshthasandhan (lobuloplasty), karnasandhan (otoplasty). In this era also rhinoplasty-Indian forehead flap described by Susruta in $600 \mathrm{BC}$ is very fascinating and is referred to as Indian flap and known as father of Surgery and Plastic surgery. The present topic deals with the intensive care management procedures and planning of Süsrüta through holistic approach which can be looked into in parallel to the present techniques of 
modern research. It is believed that the concept generated by Süsrüta was no way orthodox other than holistic approach probably due to the available resources, but component expanded by his method is a matter of great concern what is prevailing now-a-days. The author has depicted the clear knowledge of related subjects required for the surgeon and probably the experts of other related disciplines are praised.

"Nahiekasminshastreshakyahsarvashastranamavarodhakartum' 'Again it has been emphasized that "Ekashastriadhoyanonavidyatshastranishchyam| Tasmatbahushrutamshastramvijaniyatchikitsaka", Su.su 4/7

It includes primarily physics for Padarth vigyan, Chemistry for Rasa-Rasayana, Botany for Vanaspati, and Anatomy for Sharira shastra. Sushruta has emphasized for a must to read as"Etadavashayaadhyeyamadhityachakarmaniavashyaupasitavyamubhyogyon $\mid$ hi bhishakrajarhobhavati' 'Su.su.3/47

Similarly, a physician should be trained from both medicine (Kayachikitsa) and surgery (Shalya-tantra) to manage a patient of need as:-

"Snehadishuanabhigyonjechedyadishu cha karmasu

Tenihantijananlobhatkuvaidyonrupadhoshatah' 'Su.su $3 / 52$

Basically, Süsrūta Samhitā is text of surgery and that is why he has emphasized primarily on the text.

"Asminshastrashastrakarmapradhanyatshastra-

karmevatavat

Purvaupadekshama tat sambaharascha"Su.su.5/4

Sūsrūtais regarded as "SharireSūsrūtaSrestham" which denotes the expertise in anatomy, physiology and surgery as-

"Sharirechaivashastre cha drishtarthavishardha Drusthashrutabhyamsandehamuhapohayahcharetkriyah"

\section{Said in Geeta}

"Edamshariramkaunteyamkshetramityamvidiyate."

In order to clear the doubts and unknown things specially the veins, arteries, nerves, bones, joints, vital parts, visceral organs are essential to confirm by practical dissection of human body after which operative measures are planned out.

\section{DISCUSSIONS}

Süsrüta has very categorically elaborated the intensive care procedures after operative procedures are completed for which the holistic approach with deeper meanings are buried in his writing's. If we look into the present scenario in modern treatment, usually the experts of other disciplines are invited to look into the related disciplinary conditions as we may see in his descriptions. He had realized the probable problems of various systems of body and advised to pray various god and goddess to protect for stability of the patients as we experience in the ICU management in modern systems.

In Su.su 5/20-32the above reference the ancient system of intensive care has been elaborated by surgeon Süsrüta in which he has mentioned a detail holistic approach through shaloka for management of postoperative complications. He has emphasized full sterilization system before and after surgical procedures which indicate the knowledge of sterilization system was prevailing during this time in Ayurveda. It would be worthwhile to mention here that the procedures so adopted are quite identical as to the present system in modern medical science. He has experienced the probable post-operative complications and tried to manage in a logistic manner. Usually during and after surgical procedures critical care needs the supervision of super specialist of system concern similarly, it is apprehended that Süsrüta has described the role and responsibilities of experts of various discipline and looking to the system concern to soma, vāyu like names might have been given moreover, it is also an evidence of devavyapshra chitiksa prevailing during those days as a result in order to protect the patient from various probable complications soma (nourishes and sustains), $v \bar{a} y u$ (air elements) like representatives were being worshiped for.

Apart from above discussions it is analyzed that the knowledge of Süsrūta on infection was very much deep and he has emphasized on individual problems separately. He has also clearly explained endless surgical procedures and warned the patients who will undergone those procedures, should be protected from various bacteria's, viruses etc. as defined- 


\section{"Nishācharebhyohrakshystunityamevakshyatāturah"} It clearly defines that pre- and post-operative preparations, sterilization of instruments are must before and after surgical procedures. In details how individual systemic infections are to be protected have been described in Shaloka no.20-32 of sutra sthāna.

The description educates us about the prime aim and precautions after surgical intervention with all aseptic measures with dhoopan karma (fumigation process) so as the sterilization which is otherwise called as fumigation in modern. It is well known fact that how high quality of care for a patient is needed for a sur- gery. Based on that concept of description probable complication of various organs and systems can be anticipated. A doctrine along with the area of specialization has been hypothetically compared that with the present ICU conditions and their intensive care management procedures. The whole idea or theme probably denotes the precaution and the conditions to be encountered during surgical procedures.

A comparative scenario can be seen with today's modern specialty and the age-old management procedures. The details of deciphering the classical words are projected here under-

\begin{tabular}{|c|c|}
\hline $\begin{array}{l}\text { Requirement of experts as per Süsrüta during } \\
\text { intensive care }\end{array}$ & Similar activities as per modern ICU system \\
\hline $\begin{array}{l}\text { 1.Krutyānampratighatarthrakshobhaya } \\
\text { (Infection controlling procedures) }\end{array}$ & $\begin{array}{l}\text { In order to combat infection- Proper fumigation, sterilization of in- } \\
\text { struments and pre and post-operative precautions. }\end{array}$ \\
\hline $\begin{array}{l}\text { 2.Brahm anumodana } \\
\text { (Permission of the authority) }\end{array}$ & $\begin{array}{l}\text { Surgery to be taken under supervision of surgical unit head along with } \\
\text { informed consent of patient }\end{array}$ \\
\hline $\begin{array}{l}\text { 3.Naga, pishäch, gandharv, yaksh, rakshasharchita } \\
\text { (There are specific invisible creatures causing pain) }\end{array}$ & $\begin{array}{l}\text { Accidents, Infections and numerous reasons for pain-Painkillers, An- } \\
\text { tibiotics, Analgesics etc. required as per disease condition. }\end{array}$ \\
\hline $\begin{array}{l}\text { 4. Räkshasnishacharacharantiākashprithivi } \\
\text { (To control the movement of bacteria etc.) }\end{array}$ & $\begin{array}{l}\text { To create bacteria free condition in and around the patient's room and } \\
\text { usually no other persons are allowed except physician, specific nurs- } \\
\text { ing staff with disposable shoe and masks etc. to be provided, because } \\
\text { visitors are major source of infections. }\end{array}$ \\
\hline $\begin{array}{l}\text { 5. Brahmrishi, devrishi, rajshri, parvat, Nadhi, } \\
\text { samud (experts to save the patients) }\end{array}$ & $\begin{array}{l}\text { Experts of different related department to check up the patient for } \\
\text { promise stable condition. }\end{array}$ \\
\hline $\begin{array}{l}\text { 6. Agni rakshantuthejihwa } \\
\text { (Inviting Agni for protecting the jihva) }\end{array}$ & Gastroenterologist supervision for GIT difficulties. \\
\hline 7. Prananvāyu(Inviting vayu(air)for Prana (life )) & Cardiologist for heart and blood pressure. \\
\hline $\begin{array}{l}\text { 8. UdānaVidyut } \\
\text { (Inviting vidyuta for protection of } u d a n a \text { ) }\end{array}$ & $\begin{array}{l}\text { Cardio-thoracic checkup by concerned } \\
\text { Specialist. }\end{array}$ \\
\hline $\begin{array}{l}\text { 9. Samānamstanyaetnava } \\
\text { (Inviting samana for protecting abdomen) }\end{array}$ & Ultrasonologist for visceral dysfunction if any. \\
\hline 10. Indra for satva(purity) and bala (strength) & $\begin{array}{l}\text { Medicine specialist for general debility which } \\
\text { may require saline. (payah-peti) etc. }\end{array}$ \\
\hline $\begin{array}{l}\text { 11-15. Manu for griva, sira, (E.N.T) } \\
\text { Vaisvanarfor sira (venology) } \\
\text { Vishnu for prakrama(Neurology) } \\
\text { Purshottamfor paurush(Neuro) } \\
\text { Druvafor bhruvaatmanam(Psychiatry) } \\
\text { Ghandarvafor Satva(Purity) }\end{array}$ & $\begin{array}{l}\text { Neurologist, neuro-surgery specialist along } \\
\text { with medicine specialists etc. for concerned } \\
\text { disease condition. }\end{array}$ \\
\hline $\begin{array}{l}\text { 16-20. Varun for Prajyan } \\
\text { Chandramafor mana (mind) } \\
\text { Brahamafor } \bar{a} t m \bar{a} \text { (soul) }\end{array}$ & $\begin{array}{l}\text { Psychiatrist counseling, Neuropsychiatry } \\
\text { and experts of the discipline along with } \\
\text { spiritual motivation. }\end{array}$ \\
\hline $\begin{array}{l}\text { 21. Samundrafor nabhimandala and } \\
\text { Nimnaudara(Abdominal specialist) }\end{array}$ & Urologist for bladder retention etc. \\
\hline 22. Surya for netra (Eye care) & Ophthalmologist for any eye problem. \\
\hline 23. Dishāfor sotra (Ear care) & ENT specialist for hallucinations etc. \\
\hline
\end{tabular}




\begin{tabular}{|l|l|}
\hline 24. Nakshtraforrupa (Body luxture) & Skin and VD specialist for consultation. \\
\hline 25. Aushadhifor roma (External application) & Skin and VD specialist \\
\hline $\begin{array}{l}\text { 26. Jalafor veerya, Akasha for sharira (body) } \\
\text { Chidraand shonita (blood) }\end{array}$ & $\begin{array}{l}\text { Endocrinologist, medicine specialist } \\
\text { and hematologist also. }\end{array}$ \\
\hline 27. Ratrifor chāya (shadow) & $\begin{array}{l}\text { Gerontology / medicine /pediatric } \\
\text { Division on the basis of age }\end{array}$ \\
\hline 28. Prithavifor deha (body) & Daily nourishing and appropriate care. \\
\hline
\end{tabular}

NB-All these Ayurvedic terms used here are identical to the various specialists described by Sūsrüta in comparison to modern system of Intensive care.

\section{CONCLUSION}

The whole aim is to provide detail information of ancient system of sterilization, aseptic condition, life sustenance which can be done in ICU or in the indoor treatment with the direct supervision of multispecialty approach. Speedy recovery is essential for a patient without pain and loss of blood.

The time is still to investigate the basic principles, to evaluate the traditional concept in parallelism with modern outputs, to match the related subjects, to experiment through clinical findings as per classical diagnostic tools \& procedures, to find out and document the hidden treasure in its existing forms.

\section{REFERENCES}

1. Kewal Krishna khakral. Sūsrūtasamihitā, Sutra, nidansthan. Part-1. Varanasi: Chaukhamba Oriential; 2014.

2. Pt. Kashinath Shastri, G. N. Chaturvediet.al. Charaka Samhitā. Varanasi: Chaukhamba Vidyabhavan; 1969.

3. Brahmanand Tripathi, Kalidas Granthavali. Sanskrit Pratishtha: Chaukhamba; 2014.

4. Kalidash Nath Kalia, Shrimad Bhagavad Gita. Sanskrit Pratisthan: Chaukhamba; 2008.

5. Manuscripts of surgery. Orissa State Museum, Bhubneshwar.

\section{Source of Support: Nil \\ Conflict of Interest: None Declared}

How to cite this URL: Rinky Thakur et al: Sūsrūtasystem Of Intensivecare - A Prospective Overview. International Ayurvedic Medical Journal \{online\} 2020 \{cited August, 2020\} Available from: http://www.iamj.in/posts/images/upload/4185_4189.pdf 